\title{
Obestatin prevents analgesic tolerance to morphine and reverses the effects of mild morphine withdrawal in mice
}

\author{
Nándor Lipták, Roberta Dochnal ${ }^{1}$, Krisztina Csabafi, Júlia Szakács, Gyula Szabó * \\ Department of Pathophysiology, Faculty of Medicine, University of Szeged, Szeged, Hungary
}

\section{A R T I C L E I N F O}

\section{Article history:}

Received 10 January 2013

Received in revised form 26 April 2013

Accepted 13 July 2013

Available online 24 July 2013

\section{Keywords:}

Analgesia

Mice

Mild morphine withdrawal

Naloxone

Obestatin

\begin{abstract}
A B S T R A C T
Obestatin is a 23-amino acid gut-derived neuropeptide, encoded by the same gene with ghrelin. The goal of this study was to examine the effects of obestatin on the acute and chronic analgesic actions of morphine and on mild morphine withdrawal. Open-field (OF) and elevated plus maze (EPM) tests were used to assess mild morphine withdrawal-induced behavior changes and the heat-radiant tail-flick assay was used to investigate analgesic actions of morphine. CFLP male mice were treated twice a day with graded doses of morphine in EPM and OF experiments and once a day in tail-flick studies. Obestatin $(1.5 \mu \mathrm{g} / 2 \mu \mathrm{l})$ was administrated once a day in all experiments. Furthermore, $0.2 \mathrm{mg} / \mathrm{kg}$ naloxone or saline was administered after the final injection of morphine at a dose of $20 \mathrm{mg} / \mathrm{kg}$ in EPM and OF. These behavioral parameters were monitored in the OF: the percentage of center ambulation time and distance; whereas in the EPM: the time spent in open arms and the entries into open arms compared to the total time (\%OAT) and entries (\%OAE). In the OF, obestatin significantly decreased the percentage of time spent in the center in mice undergoing naloxone-precipitated mild morphine withdrawal. EPM results were similar to open field, but obestatin had no significant effect on parameters mentioned above. Besides, obestatin maintained the analgesic effect of morphine 90 and $120 \mathrm{~min}$ after morphine injection in mice treated with morphine receiving obestatin compared to mice treated with morphine. In tolerance studies, obestatin diminished the analgesic tolerance to morphine on the 5th day. In this study we confirmed that obestatin reversed the effect of mild morphine withdrawal and enhances the analgesic effect of morphine. These data suggest that obestatin may have a role in opioid-induced analgesia and in behavioral responses induced by opioid withdrawal.
\end{abstract} (c) 2013 Elsevier B.V. All rights reserved.

\section{Introduction}

In 2005, a ghrelin-associated peptide derived from the preproghrelin was discovered by Zhang et al. [1] and named obestatin. Obestatin was purified from the rat stomach and was initially reported to reduce food intake, gastric emptying and intestinal motility [1,2]. It was also characterized as an activator of the orphan G protein-coupled GPR39 receptor and was found to be the main ligand for it. The highest levels of GPR39 mRNA were detected by in-situ hybridization in the amygdala, the hippocampus, and the auditory cortex, while lower levels were found in several other brain regions but surprisingly no expression of GPR39 was found in the hypothalamus in mice [3]. GPR39 receptor has two splice variants, GPR39-1a and GPR39-1b. GPR39-1a is expressed selectively in the gastrointestinal tract, whereas GPR39-1b has a wider expression pattern, including nuclei in the central nervous system, for example the

\footnotetext{
The authors have no conflicts of interest to declare.

* Corresponding author at: Department of Pathophysiology, Faculty of Medicine, University of Szeged, Semmelweis u. 1, Pf. 427, H-6701 Szeged, Hungary. Tel.: + 3662 545 994; fax: + 3662545710 .

E-mail address: szabo.gyula@med.u-szeged.hu (G. Szabó).

1 Present address: Department of Child and Adolescent Psychiatry, Faculty of Medicine, University of Szeged, Szeged, Hungary.
}

amygdala, and hippocampus [4]. Later studies reported that GPR39 may not have obestatin as a main ligand [5-7]. After these findings, Zhang et al. confirmed that their original result was unreproducible [8] and subsequent results suggested that glucagon-like peptide- 1 receptor (GLP-1R) is the receptor of obestatin [9,10]. Moreover, a few in vitro studies claimed that obestatin stimulated ERK1/2 phosphorylation, in rat tumor somatotroph cells [11]; in human pancreatic islet microendothelial cells [10]; in human $\beta$ cells [9] and in human retinal pigment epithelial cells [12].

In the past few years the metabolic and body weight-regulating effect of obestatin has been investigated in detail, however, there are only a few reports, which examined the role of obestatin in exploratory behavior and its analgesic effect. A previous study on the EPM indicated that obestatin induced the elevation of the \%OAT and \%OAE in rat [13]. These data were later confirmed by Ishitobi et al. [14]: intracerebroventricular administration of antisense DNA for GPR39-1b caused anxiolytic-like effect in rats in two different behavioral tests. The same research group discovered that ghrelin decreased the \%OAT in the EPM and increased the ambulation time in the OF test in rats and neonatal chicks $[15,16]$, hence ghrelin exerts opposite effects on behavioral patterns. The role of ghrelin in reward (see reviews in this issue: $[17,18]$ ) and in anxiety (see review: [19]) are well-examined research areas, but the role of obestatin in these research fields has not been clarified yet. 
Thus, the aim of the present study was to investigate the actions of obestatin on morphine-induced analgesia and on mild morphine withdrawal in mice using three behavioral methods.

\section{Materials and methods}

\subsection{Animals}

Male CFLP white mice (30 $\pm 5 \mathrm{~g}$ of weight) of an outbred strain (Domaszék, Hungary) were used. They were kept under a standard light-dark cycle (lights on between 07.00 and $19.00 \mathrm{~h}$ ) with food and water available ad libitum. The animals were kept and treated according to the rules of the Ethical Committee for the Protection of Animals in Research (Faculty of Medicine, University of Szeged, Hungary).

\subsection{Surgery}

For intracerebroventricular (i.c.v.) cannulation, the mice were anesthetized with an intraperitoneal (i.p.) injection of Sodium Pentobarbital (Nembutal®, Phylaxia-Sanofi, Budapest, Hungary; $50 \mathrm{mg} / \mathrm{kg}$ ), and a polyethylene cannula was inserted into the right lateral cerebral ventricle and cemented to the skull with cyanoacrylate-containing instant glue. The experiments were started 4 days after i.c.v. cannulation. Upon conclusion of the experiments, $10 \mu \mathrm{l}$ of methylene blue were injected into the cerebral ventricle of the decapitated animals and the position of the cannula was inspected visually. The spread of methylene blue throughout the ventricular space indicated that the whole amount of obestatin got into the ventricles. Mice with improper cannula placement were excluded from the final statistical analysis.

\subsection{Drugs}

For intracerebroventricular (i.c.v.) treatments obestatin (Anaspec, Inc.) was dissolved in artificial cerebrospinal fluid (aCSF) and injected in a volume of $2 \mu$ l. For testing the morphine effects, subcutan (s.c.) morphine- $\mathrm{HCl}$ (Sigma-Aldrich) and naloxone-HCl (Sigma-Aldrich) injections were used. Control mice received saline s.c. and aCSF i.c.v.

\subsection{Elevated plus maze (EPM)}

The elevated plus maze (EPM) is an accepted model for studying anxiety-like behavior in mice [20]. Conditions that decrease time spent in the open arms are associated with anxiety-like behavior, whereas increased time spent in the open arms is associated with an anxiolytic effect. The EPM apparatus (Columbus Instruments, Columbus, Ohio, USA) consists of four arms (87-mm wide, 155-mm long) elevated $63.8 \mathrm{~cm}$ above the ground, with two arms enclosed by $16.3-\mathrm{cm}$-high opaque walls and illuminated with a $60 \mathrm{~W}$ light situated $1 \mathrm{~m}$ above the maze. The combination of height, luminosity and open space is assumed to induce anxiety-like behavior in mice. Behavioral testing was conducted between 10.00 and $12.00 \mathrm{~h}$. Mice were carried to the experimental room in their home cages and habituated to the laboratory for at least 30 min before testing. Only one EPM apparatus per testing room was present. The apparatus was thoroughly cleaned with ethanol (96\%) and water between mice. Mice were placed in the center of the maze facing toward an enclosed arm and behavioral activities were recorded for 10 min [21]. The following behavioral parameters were monitored: the time spent in open arms and the entries into open arms compared to the total time (\%OAT) and entries (\%OAE) and the total activity which was defined as the total number of crosses between any two arms.

\subsubsection{The effect of naloxone and obestatin on EPM behavior in mice treated with morphine}

We used twice daily injections of ascending doses of morphine (08.00 and 16.00 h.) as follows: day 1: $10 \mathrm{mg} / \mathrm{kg}$, day $2: 20 \mathrm{mg} / \mathrm{kg}$, day $3: 40 \mathrm{mg} / \mathrm{kg}$ or saline [22]. Mice were also treated once a day with either obestatin ( $1.5 \mu \mathrm{g} / 2 \mu$ l, i.c.v.) or aCSF (i.c.v.) at 08.15 h. On the test day (day 4) animals received a single dose of morphine (20 mg/ $\mathrm{kg}$, s.c.) or saline (s.c.) at $08.00 \mathrm{~h}$ and either aCSF or obestatin (i.c.v.) was given at $09.45 \mathrm{~h}$. Naloxone treatment in a dose of $0.2 \mathrm{mg} / \mathrm{kg}$, s.c. preceded behavioral assessment by $5 \mathrm{~min}$. The behavioral changes were measured for 10 min $2 \mathrm{~h}$ after the final morphine treatment with EPM $[21,23]$. The treatment of specific groups is described below (Figs. 1A, B, 2 and Table 2).

Treatment protocol was the same in the open-field.

\subsection{Open-field (OF) test}

Obestatin effects on mild morphine withdrawal were also tested by the Conducta System (Experimetria Ltd., Budapest, Hungary). The apparatus consists of five black-painted testing boxes $(40 \mathrm{~cm} \times 50 \mathrm{~cm} \times$ $50 \mathrm{~cm}$ each) set in an isolated room; the movements of mice were detected by high-density arrays of infrared diodes. One animal was placed in one box, the apparatus is able to test 5 mice at the same time and there is no connection between them. The floor of the box was washed with ethanol (96\%), water and dried prior to the next animal testing. On the test day, mice were transported to the testing room and the percentage of time spent in the center and ambulation distances in the center were recorded individually for each animal and separately for each box.

\subsubsection{The effect of graded doses of acute obestatin on OF behavior in mice}

Obestatin was administrated i.c.v. at graded doses: 0.5-2 $\mu \mathrm{g}$. Mice were tested $15 \mathrm{~min}$ after the obestatin treatment for $10 \mathrm{~min}$.

2.5.2. The effect of naloxone on OF behaviors in mice treated with obestatin

We used twice daily injections of saline. Mice were also treated once a day with either obestatin $(1.5 \mu \mathrm{g} / 2 \mu \mathrm{l}$, i.c.v., respectively) or aCSF (i.c.v.) at 08.15 h. On the test day (day 4) animals received saline (s.c.) at $08.00 \mathrm{~h}$ and either aCSF or obestatin (i.c.v.) was given at $09.45 \mathrm{~h}$. Naloxone treatment in a dose of $0.2 \mathrm{mg} / \mathrm{kg}$, s.c. preceded behavioral assessment by $5 \mathrm{~min}$. The behavioral changes were measured $2 \mathrm{~h}$ after the final saline treatment in the OF. See the specific treatments under Fig. 3A, B and Table 1.

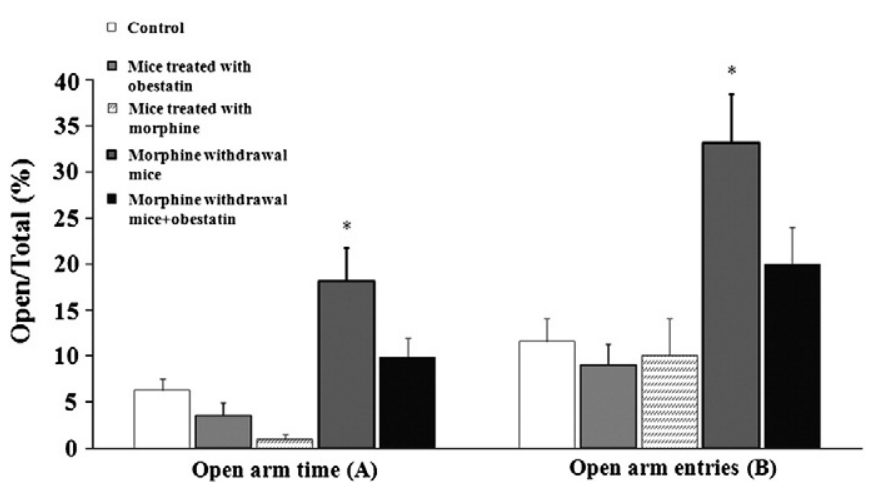

Fig. 1. A, B: The effect of naloxone and obestatin on EPM behavior (\%OAT and \%OAE) in mice treated with morphine. The graded doses of morphine $(\mathrm{mg} / \mathrm{kg}$, s.c. per injection) or saline were given twice daily for 3 days (day 1, 10; day 2, 20; day 3, 40). On day 4, naloxone $(0.2 \mathrm{mg} / \mathrm{kg})$ or saline was administered $2 \mathrm{~h}$ after the final injection of morphine at a dose of $20 \mathrm{mg} / \mathrm{kg}$, and the EPM behavior was measured $5 \mathrm{~min}$ after naloxone injection. Mice were also treated once a day with either obestatin $(1.5 \mu \mathrm{g} / 2 \mu \mathrm{l})$ or aCSF i.c.v 15 min after morphine injection for 3 days. On day 4 , obestatin or aCSF was administrated 15 min prior to test. Numbers of mice: control: 8 , mice treated with morphine: 9 morphine withdrawal mice: 8 , morphine withdrawal mice + obestatin: 7 , mice treated with obestatin: 8. Bars represent the \%OAT (Fig. 1A) and the \%OAE (Fig. 1B), vertical lines on the top of the bars denote S.E. M. A * $P<0.05$ vs. control mice, mice treated with morphine and mice treated with obestatin. $\mathrm{B}^{*}: P<0.05 \mathrm{vs}$. control mice, mice treated with morphine and mice treated with obestatin. 


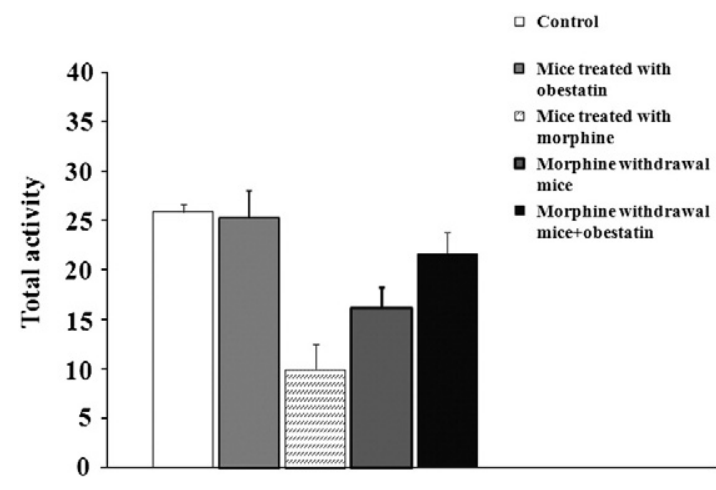

Fig. 2. The effect of naloxone and obestatin on EPM behavior (total activity) in mice treated with morphine. Treatment protocol and numbers of mice were the same as Fig. 1A and B. Bars represent the total activity; vertical lines on the top of the bars denote S.E. M.

\subsection{Tail-flick}

Obestatin effect on morphine-evoked analgesic response was tested by the tail-flick system (IITC Life Science, California, USA) described by [24]. All experiments were started with an initial tail-flick latency measurement, pain sensitivity was measured $15,30,60$ min after peptide challenge in acute dose-response experiments and 60, 90, 120 min after morphine treatment in acute morphine experiment (day 1 ). In tolerance studies, pain sensitivity was measured 60 min after morphine injection. For tail-flick measurement, animals were habituated to the experimental room at least $30 \mathrm{~min}$ prior to testing. During the measurement, they were loosely restrained and the tail was positioned so that the light beam focused on the tail approximately $1-2 \mathrm{~cm}$ from the base. Tail stimulation was delivered at different sites in consecutive measures to prevent tissue damage. The analgesic effect was expressed according to this equation:

analgesic effect $(\%)=\left(\mathrm{TFn}-\mathrm{TF}_{0}\right) /\left(\mathrm{TFmax}-\mathrm{TF}_{0}\right) \times 100$,

where $\mathrm{TF}_{0}$ is the tail-flick latency in the preliminary test mentioned above or (in tolerance studies) before morphine injection. TFn is the value of a repeated corresponding measurement $n(15,30,60$ or 60 , $90,120 \mathrm{~min}$ ) after obestatin or/and morphine injection, and TFmax indicates the cutoff (20 s).
2.6.1. The analgesic effect of graded doses of acute obestatin

Obestatin was administrated i.c.v. at graded doses: 0.5-2 $\mu$ g. Mice were tested 15, 30 and 60 min after the obestatin treatment.

2.6.2. The effect of obestatin on analgesic effect induced by acute morphine treatment (1st day)

Mice were treated $10 \mathrm{mg} / \mathrm{kg}$ morphine (s.c.) or saline (s.c.) at $09.00 \mathrm{~h}$, an hour before the first tail-flick measurement. Obestatin or aCSF were injected i.c.v. at 09.45 h. The analgesic response was measured 60, 90 and 120 min after the morphine injection.

\subsubsection{The effect of obestatin on analgesic tolerance to morphine}

To develop morphine tolerance, mice received either morphine (10 mg/kg, s.c.) or saline twice daily for four days, at 09.00 and $16.00 \mathrm{~h}[25,26]$. Mice were also treated with either obestatin or aCSF once a day at $09.45 \mathrm{~h}$. On the fifth day, morphine was administrated only in the morning at $09.00 \mathrm{~h}$. Obestatin treatment was the same as in the previous days. Analgesic effect was measured on the 1st, 3rd and 5 th days in the morning at $10.00 \mathrm{~h}$.

\subsection{Statistical analysis}

Statistical analysis of the elevated plus maze and open-field data was made by one-way analysis of variance (ANOVA) followed by Sidak posthoc test. Tail-flick experiments were analyzed using two-way repeated measures ANOVA, where drug effect (between subjects), time effect (within subjects) and their interactions were analyzed. In presence of interactions between drug and time, drug differences depend on time and vice versa, so in case of a significant interaction, drug effects were tested on each time point and time differences were tested in each group by Sidak post-hoc test. A probability value, $P<0.05$ was considered statistically significant.

\section{Results}

3.1. The effect of naloxone and obestatin on EPM behavior in mice treated with morphine

Obestatin alone had no effect on the EPM behavior compared to control mice. Obestatin treated mice undergoing withdrawal showed decreased tendency in both parameters (Fig. 1A, B) compared to the

Table 1

The effect of naloxone and obestatin on OF behavior in mice.

\begin{tabular}{|c|c|c|c|c|c|c|c|c|c|}
\hline & \multicolumn{2}{|l|}{ Day 1} & \multicolumn{2}{|l|}{ Day 2} & \multicolumn{2}{|l|}{ Day 3} & \multicolumn{3}{|l|}{ Day 4} \\
\hline & a.m. & p.m. & a.m. & p.m. & a.m. & p.m. & $\begin{array}{l}\text { 08.00-09.55 h } \\
\text { staggered }\end{array}$ & $\begin{array}{l}1 \mathrm{~h} 45 \text { min later } \\
\text { staggered } 09.45-11.45 \mathrm{~h}\end{array}$ & $\begin{array}{l}1 \mathrm{~h} \text { and } 55 \mathrm{~min} \text { later } \\
\text { staggered } 09.55-12.00 \mathrm{~h}\end{array}$ \\
\hline 1 & Sal. + aCSF & Sal. & Sal. + aCSF & Sal. & Sal. + aCSF & Sal. & Sal. & $\mathrm{aCSF}$ & Sal. \\
\hline 2 & Sal. + aCSF & Sal. & Sal. + aCSF & Sal. & Sal. + aCSF & Sal. & Sal. & $\mathrm{aCSF}$ & $\mathrm{N}: 0.2 \mathrm{mg} / \mathrm{kg}$ \\
\hline 3 & Sal. + obestatin & Sal. & Sal. + obestatin & Sal. & Sal. + obestatin & Sal. & Sal. & Obestatin & $\mathrm{N}: 0.2 \mathrm{mg} / \mathrm{kg}$ \\
\hline
\end{tabular}

Table 2

The effect of naloxone and obestatin on EPM and OF behavior in mice treated with morphine.

\begin{tabular}{|c|c|c|c|c|c|c|c|c|c|}
\hline & \multicolumn{2}{|l|}{ Day 1} & \multicolumn{2}{|l|}{ Day 2} & \multicolumn{2}{|l|}{ Day 3} & \multicolumn{3}{|l|}{ Day 4} \\
\hline & a.m. & p.m. & a.m. & p.m. & a.m. & p.m. & $\begin{array}{l}08.00- \\
09.55 \mathrm{~h} \\
\text { staggered }\end{array}$ & $\begin{array}{l}1 \mathrm{~h} 45 \mathrm{~min} \\
\text { later staggered } \\
09.45-11.45 \mathrm{~h}\end{array}$ & $\begin{array}{l}1 \mathrm{~h} \text { and } 55 \mathrm{~min} \\
\text { later staggered } \\
09.55-12.00 \mathrm{~h}\end{array}$ \\
\hline 1 & Sal. + aCSF & Sal. & Sal. + aCSF & Sal. & Sal. + aCSF & Sal. & Sal. & $\mathrm{aCSF}$ & Sal. \\
\hline 2 & $\mathrm{M} 10 \mathrm{mg} / \mathrm{kg}$ and aCSF & M $10 \mathrm{mg} / \mathrm{kg}$ & M $20 \mathrm{mg} / \mathrm{kg}$ and aCSF & M $20 \mathrm{mg} / \mathrm{kg}$ & $\mathrm{M} 40 \mathrm{mg} / \mathrm{kg}$ and $\mathrm{aCSF}$ & $\mathrm{M} 40 \mathrm{mg} / \mathrm{kg}$ & M 20 mg/kg & $\mathrm{aCSF}$ & Sal \\
\hline 3 & $\mathrm{M} 10 \mathrm{mg} / \mathrm{kg}$ and aCSF & $\mathrm{M} 10 \mathrm{mg} / \mathrm{kg}$ & $\mathrm{M} 20 \mathrm{mg} / \mathrm{kg}$ and $\mathrm{aCSF}$ & $\mathrm{M} 20 \mathrm{mg} / \mathrm{kg}$ & $\mathrm{M} 40 \mathrm{mg} / \mathrm{kg}$ and $\mathrm{aCSF}$ & $\mathrm{M} 40 \mathrm{mg} / \mathrm{kg}$ & M $20 \mathrm{mg} / \mathrm{kg}$ & $\mathrm{aCSF}$ & $\mathrm{N}: 0.2 \mathrm{mg} / \mathrm{kg}$ \\
\hline 4 & M $10 \mathrm{mg} / \mathrm{kg}$ and obestatin & M $10 \mathrm{mg} / \mathrm{kg}$ & M $20 \mathrm{mg} / \mathrm{kg}$ and obestatin & $\mathrm{M} 20 \mathrm{mg} / \mathrm{kg}$ & M $40 \mathrm{mg} / \mathrm{kg}$ and obestatin & $\mathrm{M} 40 \mathrm{mg} / \mathrm{kg}$ & M 20 mg/kg & Obestatin & $\mathrm{N}: 0.2 \mathrm{mg} / \mathrm{kg}$ \\
\hline 5 & Sal. + obestatin & Sal. & Sal. + obestatin & Sal. & Sal. + obestatin & Sal. & Sal. & Obestatin & Sal. \\
\hline
\end{tabular}




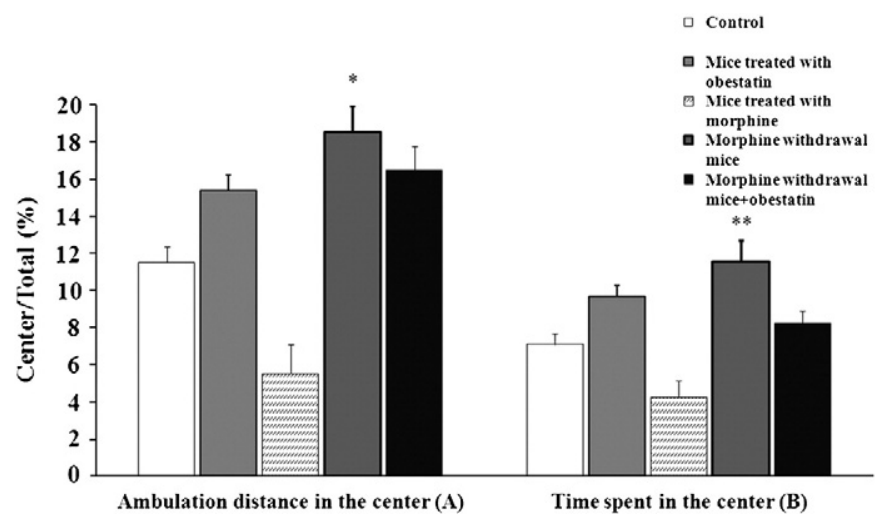

Fig. 3. A, B: The effect of naloxone and obestatin on OF behavior in mice treated with morphine. Treatment protocol was the same as naloxone-precipitated mild withdrawal EPM experiments. Numbers of mice: control: 12, mice treated with morphine: 8 , morphine withdrawal mice: 11 , morphine withdrawal mice + obestatin: 10 , mice treated with obestatin: 11. Bars represent the percentage of ambulation distance in the center (Fig. 3A) and the percentage of time spent in the center (Fig. 3B), vertical lines on the top of the bars denote S.E. M. A * $P<0.05$ vs. control mice and mice treated with morphine. $\mathrm{B}^{* *}: P<0.05$ vs. control mice, mice treated with morphine and morphine withdrawal mice receiving obestatin.

morphine withdrawal mice that did not receive obestatin, but the differences were not significant (\%OAT: $\left[\mathrm{F}_{(4,38)}=7.11, P<0.086\right]$; \%OAE: $\left[\mathrm{F}_{(4,38)}=7.11, P<0.227\right]$. Naloxone caused a significant increase in both parameters in morphine treated mice compared with control mice and mice treated with morphine $\left[\mathrm{F}_{(4,38)}=11.01, P<0.002\right]$. Morphine withdrawal mice receiving obestatin did not show significant changes in total activity compared to morphine withdrawal mice $\left[\mathrm{F}_{(4,38)}=9.243, P<0.682\right]$ (Fig. 2$)$.

\subsection{The effect of graded doses of acute obestatin on OF behavior in mice}

The $1.5 \mu \mathrm{g} / 2 \mu \mathrm{l}$ dose of obestatin had a moderate decreasing effect on the percentage of time spent in the center compared to control mice so this dose of obestatin was selected for the following experiments. See the statistical data in Table 3.

\subsection{The effect of naloxone on $\mathrm{OF}$ behavior in mice treated with obestatin}

Naloxone alone had no effect on the percentage of time spent in the center and ambulation distance in the center. Mice treated with naloxone and obestatin did not show any changes in these parameters. See the statistical data in Table 4.

3.4. The effect of naloxone and obestatin on OF behavior in mice treated with morphine

Obestatin alone had no significant effect on both parameters compared to control mice. Obestatin significantly decreased the percentage of time spent in the center in mice undergoing naloxoneprecipitated mild morphine withdrawal $\left[\mathrm{F}_{(4,51)}=10.998, P<0.045\right]$ (Fig. 3B). Obestatin had no significant effect on the percentage of ambulation distance in center in mice treated with morphine and naloxone $\left[\mathrm{F}_{(4,51)}=13.149, \mathrm{P}<0.998\right]$ (Fig. $3 \mathrm{~A}$ ). Naloxone precipitated mild
Table 4

The effect of naloxone on OF behaviors in mice treated with obestatin.

\begin{tabular}{lclc}
\hline Parameters in open-field & $\begin{array}{l}\text { Saline + aCSF } \\
(9)\end{array}$ & $\begin{array}{l}\text { Naloxone } \\
(0.2 \mathrm{mg} / \mathrm{kg})+ \\
\mathrm{aCSF}(9)\end{array}$ & $\begin{array}{l}\text { Naloxone } \\
(0.2 \mathrm{mg} / \mathrm{kg})+ \\
\text { obestatin } \\
1.5 \mu \mathrm{g} / 2 \mu \mathrm{l}(8)\end{array}$ \\
\hline $\begin{array}{l}\text { The percentage of time spent } \\
\text { in the center } \pm \text { S.E.M }\end{array}$ & $7.65 \pm 0.8$ & $6.44 \pm 0.33$ & $5.69 \pm 0.37$ \\
$\begin{array}{l}\text { The percentage of ambulation } \\
\text { distances in the } \\
\text { center }+ \text { S.E.M. }\end{array}$ & $11.56 \pm 1.44$ & $10.56 \pm 0.8$ & $10.01 \pm 1.12$ \\
\hline
\end{tabular}

Numbers in brackets show the numbers of mice used in these experiments.

morphine withdrawal caused significant increase in both parameters compared control mice and mice treated with morphine (the percentage of time spent in the center: $\left[\mathrm{F}_{(4,51)}=10.998, P<0.001\right]$; the percentage of ambulation distance in the center: Fig. $3 \mathrm{~A}:\left[\mathrm{F}_{(4,51)}=13.149\right.$, $P<0.005])$

\subsection{The analgesic effect of graded doses of acute obestatin}

The $1.5 \mu \mathrm{g} / 2 \mu \mathrm{l}$ dose of obestatin had a mild analgesic effect $15 \mathrm{~min}$ after peptide administration compared to control mice $\left[\mathrm{F}_{(4,41)}=3.744\right.$, $P<0.055]$, so this dose of obestatin and time-interval were selected for the other tail-flick experiments. Drug-time interactions: (drug-time $\left[\mathrm{F}_{(4,41)}=2.260, P<0.033\right]$; time $\left[\mathrm{F}_{(4,41)}=4.001, P<0.022\right]$ were significant; drug $\left[F_{(4,41)}=1.910 . P<0.129\right]$ was not significant. See the statistical data in Table 5.

\subsection{The effect of obestatin on analgesic effect induced by acute morphine treatment (1st day)}

Mice treated with morphine showed significant higher pain sensitivity 90 and 120 min after morphine injection compared to first measurement (60 min) of the same group $\left[\mathrm{F}_{(3,28)}=12.482, P<0.001\right]$ and significant lower pain-related behavior compared with control in all time of measurements. Obestatin maintained the analgesic effect of morphine 90 and 120 min after morphine injection in mice treated with morphine receiving obestatin compared to mice treated with morphine (90 min: $\left[\mathrm{F}_{(3,28)}=6.285, P<0.01\right] ; 120$ min: $\left[\mathrm{F}_{(3,28)}=6.285, P<0.001\right]$. Drugtime interactions (drug-time $\left[\mathrm{F}_{(3,28)}=7.198, P<0.001\right]$; time $\left[\mathrm{F}_{(3,28)}=\right.$ 7.912, $P<0.003]$; drug $\left.\left[\mathrm{F}_{(3,28)}=45.175, P<0.003\right]\right)$ were significant (Fig. 4).

\subsection{The effect of obestatin on analgesic tolerance to morphine}

Morphine tolerant mice showed significant higher pain sensitivity on the 3rd and 5th days of experiments compared to the 1st day of the same group $\left[\mathrm{F}_{(3,28)}=67.693, P<0.001\right]$ and significant lower pain-related behavior compared with control on the 1 st and 3rd days, but not on the 5th day. Morphine tolerant mice receiving obestatin displayed significant higher pain sensitivity on the 5th day compared with the 1st day of the same group $\left[\mathrm{F}_{(3,28)}=8.693, P<0.001\right]$. Obestatin diminished the analgesic tolerance to morphine on the 5 th day in morphine tolerant mice receiving obestatin compared with morphine tolerant mice $\left[\mathrm{F}_{(3,28)}=\right.$ 8.693, $P<0.001]$. Drug-time interactions (drug-time $\left[\mathrm{F}_{(3,28)}=15.813\right.$,

Table 3

The effect of graded doses of acute obestatin on OF behavior in mice.

\begin{tabular}{|c|c|c|c|c|c|}
\hline Parameters in open-field & $\begin{array}{l}\text { aCSF control } \\
(16)\end{array}$ & $\begin{array}{l}\text { Obestatin } 0.5 \mu \mathrm{g} / 2 \mu \mathrm{l} \\
\text { (15) }\end{array}$ & $\begin{array}{l}\text { Obestatin } 1.0 \mu \mathrm{g} / 2 \mu \mathrm{l} \\
\text { (15) }\end{array}$ & $\begin{array}{l}\text { Obestatin } 1.5 \mu \mathrm{g} / 2 \mu \mathrm{l} \\
(10)\end{array}$ & $\begin{array}{l}\text { Obestatin } 2.0 \mu \mathrm{g} / 2 \mu \mathrm{l} \\
\text { (15) }\end{array}$ \\
\hline The percentage of time spent in the center \pm S.E.M & $6.77 \pm 0.91$ & $6.49 \pm 0.68$ & $5.71 \pm 0.59$ & $4.97 \pm 1.3$ & $6.31 \pm 0.32$ \\
\hline The percentage of ambulation distances in the center \pm S.E.M. & $7.57 \pm 0.81$ & $6.89 \pm 0.88$ & $6.85 \pm 0.69$ & $5.91 \pm 1.2$ & $6.31 \pm 0.32$ \\
\hline
\end{tabular}

Numbers in brackets show the numbers of mice used in these experiments. 
Table 5

The analgesic effect of graded doses of acute obestatin.

\begin{tabular}{|c|c|c|c|c|c|}
\hline $\begin{array}{l}\text { Analgesic } \\
\text { effect }(\%) \pm \\
\text { S.E.M }\end{array}$ & $\begin{array}{l}\text { aCSF } \\
\text { control } \\
(8)\end{array}$ & $\begin{array}{l}\text { Obestatin } \\
0.5 \mu \mathrm{g} / 2 \mu \mathrm{l} \\
(8)\end{array}$ & $\begin{array}{l}\text { Obestatin } \\
1.0 \mu \mathrm{g} / 2 \mu \mathrm{l} \\
(10)\end{array}$ & $\begin{array}{l}\text { Obestatin } \\
1.5 \mu \mathrm{g} / 2 \mu \mathrm{l} \\
(9)\end{array}$ & $\begin{array}{l}\text { Obestatin } \\
2.0 \mu \mathrm{g} / 2 \mu \mathrm{l} \\
\text { (7) }\end{array}$ \\
\hline $\begin{array}{l}15 \text { min after } \\
\text { injection }\end{array}$ & $3.26 \pm 1.26$ & $5.59 \pm 1.06$ & $6.25 \pm 1.29$ & $7.88 \pm 0.93$ & $2.53 \pm 0.68$ \\
\hline $\begin{array}{c}30 \text { min after } \\
\text { injection }\end{array}$ & $5.86 \pm 1.47$ & $5.86 \pm 1.39$ & $4.03 \pm 1.53$ & $8.64 \pm 1.47$ & $8.11 \pm 1.83$ \\
\hline $\begin{array}{l}60 \text { min after } \\
\text { injection }\end{array}$ & $5.38 \pm 1.26$ & $7.26 \pm 1.37$ & $6.15 \pm 1.41$ & $9.04 \pm 1.48$ & $5.43 \pm 1.12$ \\
\hline
\end{tabular}

$P<0.001]$; time $\left[\mathrm{F}_{(3.28)}=25.473, P<0.003\right]$; drug $\left[\mathrm{F}_{(3.28)}=62.100\right.$, $P<0.003$ ]) were significant (Fig. 5).

\section{Discussion}

In this study the effect of obestatin on mild morphine withdrawal and on analgesic action of morphine were investigated. Up to this point, it has been a poorly examined research field and the present data may provide a new orientation for obestatin research.

It is known that morphine treatment alone and naloxone precipitated morphine withdrawal increase the ERK $1 / 2$ phosphorylation in mice $[27,28]$. Moreover, ERK $1 / 2$ inhibitors can attenuate the analgesic effect evoked by morphine $[29,30]$ and block the increased open arm-time after morphine withdrawal on EPM [31]. There is no data about the effect of obestatin on ERK 1/2 pathway in the central nervous system after in vivo treatment, but obestatin might exert its effect on mild morphine withdrawal and analgesia via regulation of ERK $1 / 2$ pathway.

After chronic morphine treatment naloxone significantly increased the \%OAT and \%OAE compared to control mice and mice treated with morphine in the EPM (Fig. 1A,B). Our result supports the previous findings described by [22]. The same experimental protocol was used in the OF test. Mice undergoing mild withdrawal spent significantly more time and traveled significantly more distance in the center of the open field compared to the control mice and mice treated with morphine (Fig. 3A, B). To our knowledge this is the first study which has confirmed this effect of naloxone-precipitated mild morphine withdrawal in the open field test in mice. In contrast to the data obtained in mice, morphine administration increased \%OAT and \%OAE in rats [32-34]

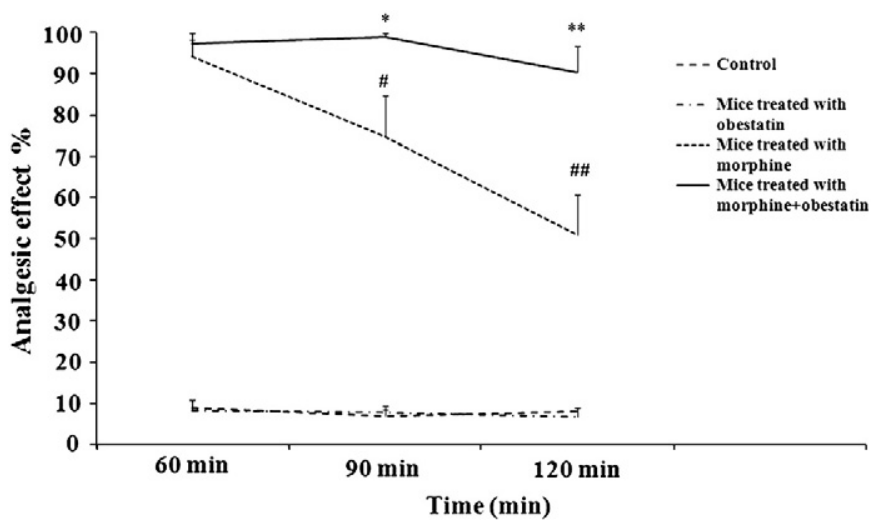

Fig. 4. The effect of obestatin on analgesic effect induced by acute morphine treatment ( $1 \mathrm{st}$ day). Mice treated with single injection of morphine at dose of $10 \mathrm{mg} / \mathrm{kg}$ or saline $(09.00 \mathrm{~h})$. Mice were also given either obestatin $(1.5 \mu \mathrm{g} / 2 \mu \mathrm{l})$ or aCSF i.c.v $45 \mathrm{~min}$ after morphine injection (09.45 h). Tail-flick latency was measured 60, 90, 120 min after morphine treatment. Bars represent the percentage of analgesic effect, vertical lines on the top of the bars denote S.E. M., *: $P<0.05$ vs. mice treated with morphine and control mice at 90th min; ${ }^{* *}: P<0.05$ vs. mice treated with morphine and control mice at 120 th min; \#: $P<0.05$ vs. mice treated with morphine at 60 th min; \#\#: $P<0.05$ vs. mice treated with morphine at 60th min and 90th min. Drug-time interactions (two-way repeated measures ANOVA): drug-time $\left[\mathrm{F}_{(3,28)}=7.198, P<0.001\right]$; time $\left[\mathrm{F}_{(3,28)}=7.912, P<0.003\right]$ drug $\left[F_{(3,28)}=45.175, P<0.003\right]$. Numbers of mice: control: 7 , mice treated with morphine: 7 , mice treated with morphine + obestatin: 8 , mice treated with obestatin: 7 .

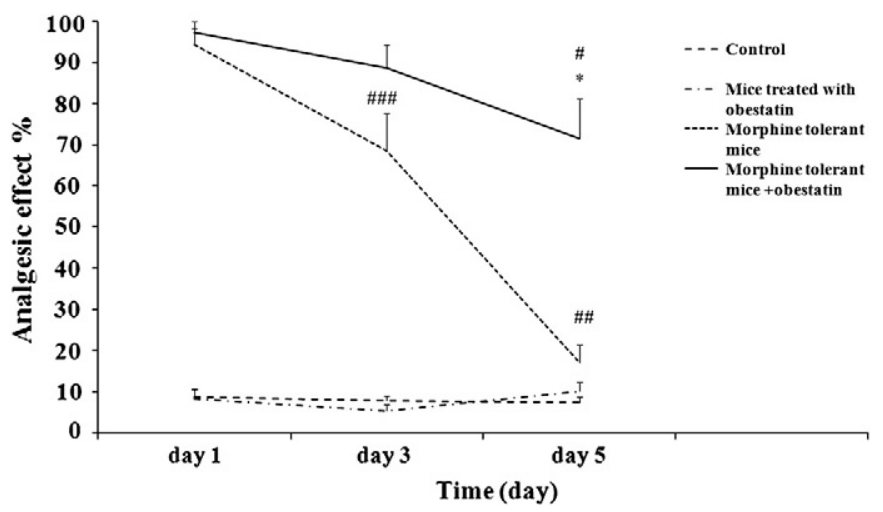

Fig. 5. The effect of obestatin on analgesic tolerance to morphine. Mice treated with morphine at doses of $10 \mathrm{mg} / \mathrm{kg}$ or saline twice a day at $09.00 \mathrm{~h}$ and $16.00 \mathrm{~h}$. Mice were also given either obestatin $(1.5 \mu \mathrm{g} / 2 \mu \mathrm{l})$ or aCSF i.c.v $15 \mathrm{~min}$ after morphine injection $(09.45 \mathrm{~h})$ once a day on the test days and at $09.15 \mathrm{~h}$ on the other days. Tail-flick latency was measured $60 \mathrm{~min}$ after morphine treatment on the 1st, 3rd and 5th days. Numbers of mice were the same as in Fig. 4. Bars represent the percentage of analgesic effect, vertical lines on the top of the bars denote S.E. M., ${ }^{*}: P<0.05$ vs. morphine tolerant mice and control mice on the 5th day; \#: $P<0.05$ vs. morphine tolerant mice receiving obestatin on the 1st day; \#\#: $P<0.05$ vs. morphine tolerant mice on the $3 \mathrm{rd}$ and 1 st day; \#\#\#: $P<0.05$ vs. morphine tolerant mice on the 1st day. Drug-time interactions (two-way repeated measures ANOVA): drug-time $\left[\mathrm{F}_{(3,28)}=15.813, P<0.001\right]$; time $\left[\mathrm{F}_{(3,28)}=\right.$ 25.473, $P<0.003]$; drug $\left[\mathrm{F}_{(3,28)}=62.100, P<0.003\right]$.

and decreased these parameters during morphine withdrawal $[21,35]$. In line with literature, naloxone alone did not alter the behavior of mice in our experiments $[22,36]$.

We injected obestatin 15 min prior to test in all experiments due to our dose-response data and rapid degradation of obestatin [37]. Obestatin showed maximal levels of ERK1/2 phosphorylation after 15 min of obestatin treatment in vitro [11]. In accordance with literature [13], obestatin alone had no effect on total activity compared with control mice (Fig. 2). Morphine withdrawal mice receiving obestatin also showed no significant changes in total activity compared to morphine withdrawal mice (Fig. 2). Chronic and acute administration of obestatin alone had no significant effect on EPM (Fig. 1A, B) and OF parameters (Fig. 3A, B), so we cannot support the results of the mentioned study in which obestatin caused a significant increase in the time spent in open arm in rats [13]. This contradiction alludes to the species-dependent impact of obestatin, although the amino acid-sequence of rat and mouse obestatin is completely the same. Obestatin displayed an inhibitory effect on \%OAT in EPM and the time spent and ambulation distance in the center of the OF undergoing withdrawal. Although, our result was not significant in the EPM tests $(P<0.086)$, it followed the same tendency that we have recorded in the open field test after naloxone treatment.

The reduction of the analgesic effect of the single injection of morphine and the analgesic tolerance to morphine were confirmed using tail-flick assay. In tail-flick we also recorded that obestatin significantly prolonged the analgesic effect of acute morphine 90 and 120 min after morphine treatment (Fig. 4) and prevented the analgesic tolerance to morphine in the fifth day of chronic morphine treatment (Fig. 5).

The physiological role of obestatin in behavior and the underlying mechanism have not been elucidated, so there has been no exact explanation of these results yet. However, obestatin is produced by the gastrointestinal tract, the peripheral obestatin might cross the bloodbrain barrier and enter the hippocampus and amygdala and by activating these brain regions they may modulate the behavior of rodents [13]. We administrated obestatin centrally in harmony with previous studies [38-41].

\section{Conclusions}

In conclusion, we observed that mice undergoing naloxone precipitated mild morphine withdrawal showed increased \%OAE and \%OAT on 
EPM and in the percentage of center ambulation time and distance in OF. We also confirmed that chronic administration of obestatin into the central nervous system significantly diminished these effects of naloxone precipitated withdrawal in OF. We also discovered that obestatin prevented the decrease of analgesic effect of acute morphine and the analgesic tolerance to morphine in tail-flick test.

Our data suggest that obestatin may have a physiological role in anxiety and analgesia regulated by the opioid system.

\section{Acknowledgments}

The authors wish to appreciatively acknowledge the technical assistance of Gusztáv Kiss, Ágnes Pál and Ildikó Sípos. This study was supported by ETT-Grant (355-08/2009); TÁMOP 4.2.1./B-09/KONV2010-0005 and TÁMOP-4.2.2/B-10/1-2010-0012.

\section{References}

[1] Zhang JV, Ren PG, Avsian-Kretchmer O, Luo CW, Rauch R, Klein C, et al. Obestatin, a peptide encoded by the ghrelin gene, opposes ghrelin's effects on food intake. Science 2005;310:996-9.

[2] Bresciani E, Rapetti D, Dona F, Bulgarelli I, Tamiazzo L, Locatelli V, et al. Obestatin inhibits feeding but does not modulate $\mathrm{GH}$ and corticosterone secretion in the rat. J Endocrinol Invest 2006;29:16-8.

[3] Jackson VR, Nothacker HP, Civelli O. GPR39 receptor expression in the mouse brain. Neuroreport 2006;17:813-6.

[4] Egerod KL, Holst B, Petersen PS, Hansen JB, Mulder J, Hokfelt T, et al. GPR39 splice variants versus antisense gene LYPD1: expression and regulation in gastrointestinal tract, endocrine pancreas, liver, and white adipose tissue. Mol Endocrinol 2007;21: $1685-98$.

[5] Lauwers E, Landuyt B, Arckens L, Schoofs L, Luyten W. Obestatin does not activate orphan G protein-coupled receptor GPR39. Biochem Biophys Res Commun 2006;351: 21-5.

[6] Chartrel N, Alvear-Perez R, Leprince J, Iturrioz X, Reaux-Le GA, Audinot V, et al. Comment on "Obestatin, a peptide encoded by the ghrelin gene, opposes ghrelin's effects on food intake". Science 2007;315:766.

[7] Holst B, Egerod KL, Schild E, Vickers SP, Cheetham S, Gerlach LO, et al. GPR39 signaling is stimulated by zinc ions but not by obestatin. Endocrinology 2007;148:13-20.

[8] Zhang JV, Klein C, Ren PG, Kass S, Donck LV, Moechars D, et al. Response to comment on "Obestatin, a peptide encoded by the ghrelin gene, opposes ghrelin's effects on food intake". Science 2007;315:766.

[9] Granata R, Settanni F, Gallo D, Trovato L, Biancone L, Cantaluppi V, et al. Obestatin promotes survival of pancreatic $\beta$ cells and human islets and induces expression of genes involved in the regulation of $\beta$ cell mass and function. Diabetes 2008:57:967-79.

[10] Favaro E, Granata R, Miceli I, Baragli A, Settanni F, Perin PC, et al. The ghrelin gene products and exendin- 4 promote survival of human pancreatic islet endothelial cells in hyperglycaemic conditions, through phosphoinositide 3-kinase/Akt, extracellular signal-related kinase (ERK)1/2 and cAMP/protein kinase A (PKA) signalling pathways. Diabetologia 2012;55:1058-70.

[11] Pazos Y, Alvarez CJ, Camina JP, Al-Massadi O, Seoane LM, Casanueva FF. Role of obestatin on growth hormone secretion. Biochem Biophys Res Commun 2009;390:1377-81.

[12] Camiña JP, Campos JF, Caminos JE, Dieguez C, Casanueva FF. Obestatin-mediated proliferation of human retinal pigment epithelial cells: regulatory mechanisms. J Cell Physiol 2007;211:1-9.

[13] Carlini VP, Schioth HB, de Barioglio SR. Obestatin improves memory performance and causes anxiolytic effects in rats. Biochem Biophys Res Commun 2007;352:907-12.

[14] Ishitobi Y, Akiyoshi J, Honda S, Ninomiya T, Kanehisa M, Tanaka Y, et al. Administration of antisense DNA for GPR39-1b causes anxiolytic-like responses and appetite loss in rats. Neurosci Res 2012;72:257-62.

[15] Carlini VP, Monzon ME, Varas MM, Cragnolini AB, Schioth HB, Scimonelli TN, et al. Ghrelin increases anxiety-like behavior and memory retention in rats. Biochem Biophys Res Commun 2002;299:739-43.

[16] Carvajal P, Carlini VP, Schioth HB, de Barioglio SR, Salvatierra NA. Central ghrelin increases anxiety in the Open Field test and impairs retention memory in a passive avoidance task in neonatal chicks. Neurobiol Learn Mem 2009;91:402-7.
[17] Dickson SL, Egecioglu E, Landgren S, Skibicka KP, Engel JA, Jerlhag E. The role of the central ghrelin system in reward from food and chemical drugs. Mol Cell Endocrinol 2011;340:80-7.

[18] Skibicka KP, Dickson SL. Ghrelin and food reward: the story of potential underlying substrates. Peptides 2011;32:2265-73.

[19] Andrews ZB. The extra-hypothalamic actions of ghrelin on neuronal function. Trends Neurosci 2011;34:31-40.

[20] Lister RG. The use of a plus-maze to measure anxiety in the mouse. Psychopharmacology 1987; $92: 180-5$.

[21] Schulteis G, Yackey M, Risbrough V, Koob GF. Anxiogenic-like effects of spontaneous and naloxone-precipitated opiate withdrawal in the elevated plus-maze. Pharmacol Biochem Behav 1998;60:727-31.

[22] Hodgson SR, Hofford RS, Norris CJ, Eitan S. Increased elevated plus maze open-arm time in mice during naloxone-precipitated morphine withdrawal. Behav Pharmacol 2008;19:805-11.

[23] Higgins GA, Sellers EM. Antagonist-precipitated opioid withdrawal in rats: evidence for dissociations between physical and motivational signs. Pharmacol Biochem Behav 1994;48:1-8.

[24] D'Amour FE, Smith DL. A method for determining loss of pain sensation. J Pharmacol Exp Ther 1941;72(1941):74-9.

[25] Mamiya T, Noda Y, Ren XH, Hamdy M, Furukawa S, Kameyama T, et al. Involvement of cyclic AMP systems in morphine physical dependence in mice: prevention of development of morphine dependence by rolipram, a phosphodiesterase 4 inhibitor. Br J Pharmacol 2001;132:1111-7.

[26] Mamiya T, Noda Y, Ren X, Nagai T, Takeshima H, Ukai M, et al. Morphine tolerance and dependence in the nociceptin receptor knockout mice. J Neural Transm 2001;108: 1349-61.

[27] Li Tao, Houc Ying, Caoc Wei, Yana Chun-xia, Chena Teng, Sheng-bing. Naloxoneprecipitated withdrawal enhances ERK phosphorylation in prefrontal association cortex and accumbens nucleus of morphine-dependent mice. Neurosci Lett 2010;468: 348-52.

[28] Park SH, Sim YB, Kang YJ, Kim CH, Kwon MS, Suh HW. The differential profiles of withdrawal symptoms induced by morphine and beta-endorphin administered intracerebroventricularly in mice. Neuroscience 2012;218:216-25.

[29] Komatsu T, Sakurada C, Sasaki M, Sanai K, Tsuzuki M, Bagetta G, et al. Extracellular signal-regulated kinase (ERK) and nitric oxide synthase mediate intrathecal morphine-induced nociceptive behavior. Neuropharmacology 2007;52(2007): 1237-43.

[30] Komatsu T, Sakurada S, Kazuhiro Kohno K, Shiohira H, Katsuyama S, Sakurada C, et al. Spinal ERK activation via NO-cGMP pathway contributes to nociceptive behavior induced by morphine-3-glucuronide. Biochem Pharmacol 2009;78:1026-34.

[31] Hofford RS, Hodgson SR, Roberts KW, Bryant CD, Evans CJ, Eitan S. Extracellular signal-regulated kinase activation in the amygdala mediates elevated plus maze behavior during opioid withdrawal. Behav Pharmacol 2009;20:576-83.

[32] Koks S, Soosaar A, Voikar V, Bourin M, Vasar E. BOC-CCK-4, CCK(B)receptor agonist, antagonizes anxiolytic-like action of morphine in elevated plus-maze. Neuropeptides 1999;33:63-9.

[33] Zarrindast MR, Sarahroodi S, Arzi A, Khodayar MJ, Taheri-Shalmani S, Rezayof A. Cannabinoid CB1 receptors of the rat central amygdala mediate anxiety-like behavior: interaction with the opioid system. Behav Pharmacol 2008;19:716-23.

[34] Rezayof A, Hosseini SS, Zarrindast MR. Effects of morphine on rat behaviour in the elevated plus maze: the role of central amygdala dopamine receptors. Behav Brain Res 2009;202:171-8.

[35] Zhang Z, Schulteis G. Withdrawal from acute morphine dependence is accompanied by increased anxiety-like behavior in the elevated plus maze. Pharmacol Biochem Behav 2008;89:392-403.

[36] Ribeiro SJ, De Lima TC. Naloxone-induced changes in tachykinin NK3 receptor modulation of experimental anxiety in mice. Neurosci Lett 1998;258:155-8.

[37] Pan W, Tu H, Kastin AJ. Differential BBB interactions of three ingestive peptides: obestatin, ghrelin, and adiponectin. Peptides 2006;27:911-6.

[38] Sibilia V, Bresciani E, Lattuada N, Rapetti D, Locatelli V, De LV, et al. Intracerebroventricular acute and chronic administration of obestatin minimally affect food intake but not weight gain in the rat. J Endocrinol Invest 2006;29:31-4.

[39] Samson WK, White MM, Price C, Ferguson AV. Obestatin acts in brain to inhibit thirst. Am J Physiol Regul Integr Comp Physiol 2007;292(2007):637-43.

[40] Samson WK, Yosten GL, Chang JK, Ferguson AV, White MM. Obestatin inhibits vasopressin secretion: evidence for a physiological action in the control of fluid homeostasis. J Endocrinol 2008;196:559-64.

[41] Chen CY, Doong ML, Li CP, Liaw WJ, Lee HF, Chang FY, et al. A novel simultaneous measurement method to assess the influence of intracerebroventricular obestatin on colonic motility and secretion in conscious rats. Peptides 2010;31:1113-7. 